\title{
A LACTATE-UTILIZING CORYNEBACTERIUM FROM THE RUMEN OF CATTLE
}

\author{
Helge Gyllenberg and Martti LAmpila
}

\begin{abstract}
Department of Microbiology, University of Helsinki, and Agricultural Research Centre, Department of Animal Husbandry, Tikkurila.
\end{abstract}

Received 28th January 1955.

Among the bacteria utilizing lactate in the rumen of sheep and cattle, types related to corynebacteria seem to occur. No conclusive evidence, however, has been offered of the exact systematic position of these organisms. Gutierrez (5) based the taxonomy of his strains on the work of Douglas and Gunter (2) who suggested that Corynebacterium acnes (Gilchrist, 4; cf. Bergey's Manual, 6th Ed., 1948) should be classified as a propionibacterium, viz. Propionibacterium acnes. This, however, must be considered a matter of interpretation, since the borderline between propionibacteria and corynebacteria is at present far from definite.

When investigating the lactate-utilizing bacteria in the rumen of cattle, one of the authors (Lampila) found considerable counts of a type obviously related to corynebacteria. The characteristics of this organism are presented below.

Rumen fluid was obtained with a tube from a dairy cow with an artificial fistula. Plated on peptone-yeast extract-lactate agar (sodium lactate $0.5 \%$, yeast extract $0.5 \%$, peptone $0.5 \%$ ) it gave aerobic counts ranging from $100000-10000000$ colonies per ml. of the fluid. Among the colonies which developed rapidly in these tests one type showing the following characteristics was frequently found: White or yellowish, moist raised colonies, which on microscopic examination were found to consist of small gram-positive rods. When subcultured in agar stabs it was found that the strain, labelled "L", showed growth of two different types. In the agar growth occurred as a thin greyish film which also spread over the surface of the stab. On the surface, however, a thick raised growth developed in 2-3 days, dirty greyish-white in colour but turning yellow in one week or ten days, and on further incubation (in about 3 weeks) brownish. Distinct differences in cell morphology correspond to the different colony types. The thin-film colony types was found to consist of irregular, often club-shaped rods, 0.8 to 1.0 by 2.5 to 4.0 microns in size (fig. 1). The heavy, coloured colony type, on the other hand, showed quite regular 


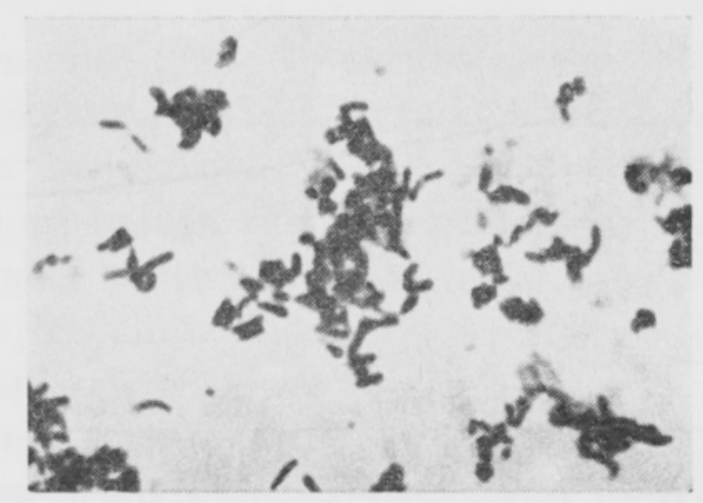

Fig. 1. Strain $"$ L». $\times 1000$, stained with crystal violet; from glucose broth.

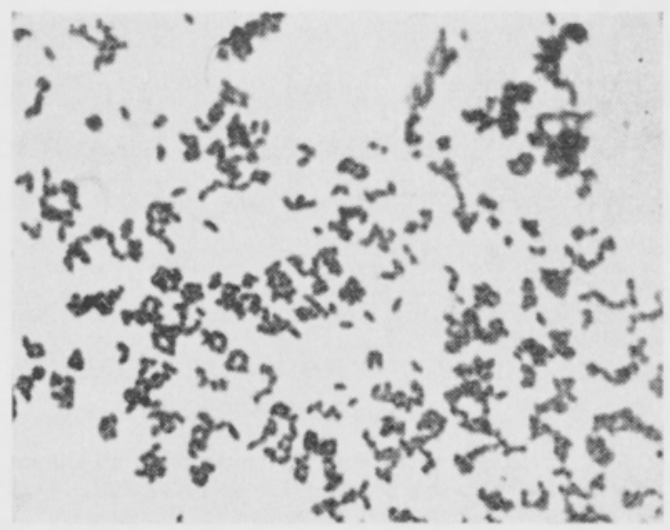

Fig. 2. Strain L". $\times 1000$, Gram-stain from agar stab.

short rods, 0.5 by 1.0 to 1.5 microns in size (fig. 2). Although quite short, the cells of the latter type were not definitely coccoid in shape. The polymorphic appearance was also readily recognizable in broth cultures. In ordinary broth an intense turbidity occurred, showing only cells of the regular short rod type, but in glucose broth the growth resulted in a heavy sedimentation in a few days, and cells of the irregular cell type were found.

The recorded properties of the strain showed a very great resemblance to Corynebacterium enzymicum (3). Some differences were, however, found compared with the description of $C$. enzymicum, especially in that strain "L" showed no distinct coccoid cell forms and failed to coagulate litmus milk. Investigations of the possible pathogenicity of the strain to rabbits, guinea pigs or mice, which is reported for C. enzymicum by EBERSON, were not made.

In Bergey's Manual both $C$. enzymicum and $C$. acnes are listed among the species occurring in human sources. Gutierrez (5), however, isolated C. acnes (Propionibacterium acnes, cf. above) from the rumen of cattle, and from soil and hay. Our isolation of C. enzymicum or a very closely related variant from the rumen of cattle confirms the suggestion of GUTIERREz that the corynebacteria earlier believed to be derived only from human sources are widely distributed in nature. The wide temperature range of our strain " $\mathrm{L}$ " (from room temperature to $39^{\circ} \mathrm{C}$ ) indicates, moreover, that the occurrence of this and related types in the rumen must be considered more or less accidental, and that their natural habitats are obviously the soil, and hay or corresponding fodders.

Experiments on the lactate utilization of strain "L" showed that considerable amounts of volatile acids were formed when fermentation was effected by resting cell preparations. In "growing cultures»" ${ }^{1}$, on the other hand, the production of volatile

1 In the experiments with resting cells and those dealing with "growing cultures" the basal substrate was the same: sodium lactate, and a phosphate buffer in a $0.1 \mathrm{M}$ concentration. In the experiments permitting an increase in the cell concentration during the experiment, "growing cultures", $0.1 \%$ yeast extract was included, in addition. In both types of experiments the initial cell concentration was the same: $10 \mathrm{ml}$ of a suspension of washed cell $\mathrm{s}$ in saline added to $40 \mathrm{ml}$ of the substrate. The possible increase in cell concentration in the experiments with "growing cultures" was not determined. 
Table 1. The fermentation of lactate by strain $» \mathrm{~L} »$. The experiments were carried out at $28^{\circ} \mathrm{C}$, and with an initial $\mathrm{pH}$ of 6.9 in the substrates.

\begin{tabular}{|c|c|c|c|c|c|c|}
\hline \multirow[b]{2}{*}{ Experiment } & & \multicolumn{2}{|c|}{ Lactate } & \multirow{2}{*}{$\begin{array}{l}\mathrm{mg} / \mathrm{ml} \text {. } \\
\text { Util- } \\
\text { ized }\end{array}$} & \multirow{2}{*}{$\begin{array}{l}\text { Volatile } \\
\mathrm{mg} \cdot / \mathrm{ml}^{1}\end{array}$} & \multirow{2}{*}{$\begin{array}{l}\text { acids produced } \\
\mathrm{mg} / \mathrm{mg} \text {. of util- } \\
\text { ized lactate }\end{array}$} \\
\hline & & $\begin{array}{l}\text { Init- } \\
\text { ally }\end{array}$ & $\begin{array}{c}\text { After } 48 \\
\text { hours }\end{array}$ & & & \\
\hline \multirow[t]{2}{*}{ Resting cells } & I & 9.38 & 7.40 & 1.98 & 0.85 & 0.43 \\
\hline & II & 9.38 & 7.38 & 2.00 & 1.05 & 0.53 \\
\hline \multirow[t]{2}{*}{ "Growing culture" } & I & 11.07 & 8.35 & 2.72 & 0.22 & 0.08 \\
\hline & II & 11.07 & 7.38 & 3.69 & 0.40 & 0.11 \\
\hline
\end{tabular}

1 These figures are calculated as acetic acid although only the total amounts of volatile acids were determined.

acids was rather slight. The results are presented in Table 1. These experiments were carried out with cells of the regular short rod type. Since the morphological type predominating in vivo has not been recorded, the fermentation experiments are of little value for computing the importance of this organism in the rumen fermentations. On the other hand, it is evident that our strain "L" is capable of utilizing lactate as the sole source of carbon by producing volatile acids.

The most interesting problem in this connection is whether organisms which obviously cannot be considered autochthonous rumen bacteria may play some role in fermentations in the rumen. According to GutierRez (5) this is true of Corynebacterium acnes, which is apparently also a casual inhabitant of the rumen. But we consider it doubtful if the topical strain "L" can be so regarded because of the relatively insignificant counts obtained. At any rate fodders may be a rich source of bacteria capable of proliferation and active life functions in the conditions of the rumen. These bacteria are corynebacteria, propionibacteria, and related types, which brings up the question as to whether the autochthonous flora of the rumen also include species of these groups. It seems that much more attention must be paid to taxonomic and ecological relationhisps in future studies of gram-positive, lactateutilizing bacteria in the rumen.

\section{Summary}

A lactate-utilizing aerobic bacterium from the rumen of cattle is described. The characteristics of the strain showed a close resemblance to Corynebacterium en zymicum, earlier considered to be derived only from human sources. The relatively low counts of the bacterium in the rumen and its relatively wide temperature range indicated that it is only a casual inhabitant of the rumen, an that its natural habitat is the soil, and hay or related materials. Since this finding is compatible with the corresponding conclusions of other authors as regards closely related corynebacteria, it can be presumed that those corynebacteria hitherto reported only from human sources may be more widely distributed in nature. 


\title{
LITERATURE
}

(1) Breed, R. S., Murray, E. G. D., and Hitchens, A. P. 1948. Bergey's Manual of determinative Bacteriology. Sixth edition. Baltimore.

(2) Douglas, H. S., and Gunter, S. E. 1946. The taxonomic position of Corynebacterium acnes, J. Bact., 52 , p. $15-23$.

(3) Eberson, 1918. Jour. Inf. Dis., 23, p. 29. Ref. Bergey's Manual of determinative Bact. 1948, p. 386.

(4) Gilchrist, T. C., 1901. Johns Hopkins Hosp. Repts. 9, p. 409-430. Ref. Bergey's Manual of determinative Bact. 1948, p. 387.

(5) Gutierrez, J. 1953. Numbers and characteristics of lactate utilizing organisms in the rumen of cattle, J. Bact., 66, p. $123-128$.

\section{SELOSTUS:}

\section{LEHMÄN PÖTSISTÄ ERISTETTY, LAKTAATTIA KÄYTTÄVÄ KORYNEBAKTEERI}

\author{
Helge Gyllenberg ja Martti Lampila
}

Helsingin Yliopiston mikrobiologinen laitos, Maatalouskoelaitoksen kotieläinhoito-osasto, Tikkurila.

Lehmän pötsistä on eristetty aerobinen laktaattia käyttävä bakteeri. Tutkitun kannan ominaisuudet osoittivat sen läheisesti muistuttavan Corynebacterium enzymicumia, joka aikaisemmin on todettu loisena vain ihmisessä. Tutkitun bakteerin suhteellisen vähäinen lukumäärä pötsissä ja sen verrattain laaja kasvulle otollinen lämpötila-alue osoittivat, että sen esiintymistä pötsissä lienee pidettävä tilapäisenä, ja että sen luonnollinen ympäristö on maa ja rehut. Koska nämä havainnot ovat sopusoinnussa muiden tutkijoiden eräitä muita korynebakteeri-lajeja koskevien tulosten kanssa, näyttää todennäköiseltä, että monet korynebakteerit, joita aikaisemmin on pidetty spesifisinä ihmisloisina, ovat huomattavan laajalle levinneitä luonnossa. 